\title{
PKM Upaya Peningkatan Kompetensi Guru di Masa Pandemi Covid-19 untuk Menunjang Pembelajaran Berbasis Digital
}

\author{
Abdul Karim¹ ${ }^{1}$, Moh. Irfan Efendi², Misbahul Huda ${ }^{3}$, \\ Moh.Sholehuddin ${ }^{4}$, Moh. Lutfi Anis ${ }^{5}$, Syaiful Huda ${ }^{6}$ \\ Fakultas Teknik Universitas Nurul Jadid Probolinggo 1,2,3,4,5,6 \\ \{karim@unuja.ac.id\}
}

Submission: 06/08/2021 Received: 14/09/2021 Published: 31/12/2021

\begin{abstract}
Keywords:
Covid-19

pandemic,

online learning,

digital-based

learning,

teacher's

competence

Abstract. Should consist of one paragraph, should not exceed 300 words, and should contain the background and objective of the community service, method/approach/strategies of community service, its principal results, and its conclusions. Since March 16, 2020, the Indonesian government has declared the COVID-19 Pandemic as an extraordinary event. The whole world has felt the impact where this pandemic has changed the life of people around the world, including in Indonesia. Almost all sectors slumped by this incident, including the education sector. In the education sector, the impact is that the change in the learning model that was originally implemented face-to-face has been changed to online learning to suppress the spread of the corona virus. This Community Service activity was carried out at Madrasah Tsanawiyah Azzainiyah 2 as the target of the activity, located in Karanganyar village, Paiton subdistrict, Probolinggo district. The participants of this activity were all subject teachers at Madrasah Tsanawiyah Azzainiyah 2. Based on the results of the analysis of participant responses, it can be concluded that the implementation of community service has gone as expected. It was proven by the participants' responses that this training can increase teacher knowledge in order to meet the demands of the times, namely digital-based learning.
\end{abstract}

Katakunci:

Pandemi Covid19, pembelajaran online, pembelajaran berbasis digital, kompetensi guru
Abstrak. Terdiri dari satu paragraf, tidak lebih dari 300 kata, berisi tentang isu dan fokus pengabdian, metode/pendekatan/strategi yang digunakan dalam riset pengabdian, dan hasil pengabdian masyarakat. Sejak tanggal 16 maret tahun 2020 pemerintah Indonesia telah menetapkan Pandemi COVID-19 sebagai kejadian luar biasa. Seluruh dunia telah merasakan dampaknya dimana pandemi ini telah mengubah tatanan kehidupan masyarakat di seluruh dunia, termasuk di Indonesia. Hampir semua sektor terpuruk akibat kajadian ini tak terkecuali sektor pendidikan. Pada sektor pendidikan dampaknya adalah perubahan model pembelajaran yang semula dilaksanakan dengan tatap muka dirubah dengan pembelajaran online untuk menekan laju penyebaran virus corona. Kegiatan Pengabdian Kepada Masyarakat ini dilakukan di Madrasah 


\begin{abstract}
Tsanawiyah Azzainiyah 2 sebagai sasaran kigiatan, lokasinya di desa Karanganyar kecamatan Paiton Kabupaten Probolinggo. Peserta dari kegiatan ini adalah semua guru mata pelajaran di Madrasah Tsanawiyah Azzainiyah 2. Berdasarkan hasil analisis tanggapan peserta dapat disimpulkan bahwa pelaksanaan pengabdian kepada masyarakat telah berjalan sesuai dengan yang diharapkan. Terukti dengan tanggapan peserta bahwa pelatihan ini dapat meningkatkan pengetahuan guru dalam rangka memenuhi tuntutan jaman yaitu pembelajaran berbasis digital.
\end{abstract}

\title{
1 Pendahuluan
}

Sejak tanggal 16 maret tahun 2020 pemerintah Indonesia telah menetapkan Pandemi COVID-19 sebagai kejadian luar biasa. Seluruh dunia telah merasakan dampaknya dimana pandemi ini telah mengubah tatanan kehidupan masyarakat di seluruh dunia, termasuk di Indonesia. Hampir semua sektor terpuruk akibat kajadian ini tak terkecuali sektor pendidikan. Pada sektor pendidikan dampaknya adalah perubahan model pembelajaran yang semula dilaksanakan dengan tatap muka dirubah dengan pembelajaran online untuk menekan laju penyebaran virus corona. Berdasarkan pernyataan organisasi kesehatan dunia baik WHO, UNICEF dan IRC pada tahun 2020 menyatakan bahwa ketika persebaran virus semakin cepat maka pembelajaran disekolah perlu dialihkan ke pembelajaran online. Sehingga untuk mencegah penularan virus corona disekolah maka Kementerian Pendidikan dan Kebudayaan mengelurkan surat edaran No. 4 tahun 2020 tentang Pelaksanaan Pendidikan dalam Masa Darurat Corona Virus Disease (Covid-19) untuk mengatur pelaksanaan pembelajaran online.

Sejak wabah Corona virus menghantam Indonesia, pemerintah memberlakukan berbagai peraturan ketat untuk mencegah penularan yang lebih meluas lagi. Salah satunya kebijakan bagi dunia pendidikan yakni pembelajaran jarak jauh. Pembelajaran jarak jauh ini merupakan kebijakan yang dikeluarkan pemerintah, khususnya Kemendikbud dan Kemenristek/BRIN, untuk mencegah penyebaran COVID-19 di sekolah. Pembelajaran Jarak Jauh dirancang agar siswa/mahasiswa bisa belajar secara virtual dengan memanfaatkan teknologi informasi dan komunikasi (TIK).

Dilansir dari situs Kompas.com pada tanggal 24 Maret 2020 Menteri Pendidikan dan Kebudayaan menegaskan baha bagi semua guru, anak, dan bagi Kemendikbud untuk mengantisipasi ini terjadi begitu cepat, artinya 
semau harus belajar sangat cepat bagaimana bisa beradaptasi terhadap belajar dari rumah. Itu artnya semua harus bisa beradaptasi dengan baik dalam pembelajaran jarak jauh ini. Tidak hanya siswa akan tetapi bagi guru. Akan tetpi banyak ekndala yang dihadapi baik oleh guru, anak didik, bahkan orang tua murid sebagai akibat dari perubahan model pembelajaran tatap muka (offline) menjadi pembelajaran secara online. Pembelajaran jarak jauh (PJJ) yang telah dikasanakan sejak awal pandemi dinilai belu efektif (Saubani, 2020). Pembelajaran jarak jauh didominasi dengan pemberian tugas dan minim interaksi antara guru dan siswa ( Heni, 2021) .Menurut Listyarti (2020) berdasarkan survey yang dilakukan Komisi Perlindungan Anak Indonesia (KPAI) bahwa 79,9\% menyatakan bahwa Pembelajaran Jarak Jauh (PJJ) berlangsung tanpa interkasi guru-siswa sama sekali kecuali untuk memberikan tugas dan menagih tugas saja. Hanya $8 \%$ guru yang telah terbiasa melakukan pembelajaran berbasis digital (Listyarti, 2020).

Pembelajaran jarak jauh dinilai belum efektif dan maksimal apabila diterapkan pada sekolah yang infrastrukturnya belum memadai. Hal ini dapat terjadi karena pembelajaran jarak jauh berbasis teknologi memerlukan pendekatan yang berbeda dalam hal perencanaan, pelaksana dan evaluasinya. Pelaksanaan pembelajaran jarak jauh, peserta didik membutuhkan perhatian khusus, terutama sarana prasarana yang digunakan, jaringan internet yang memadai dan motivasi diri agar dapat mengikuti proses pembelajaran yang bersifat mandiri (Fahrudin, 2020).

Menteri pendidikan pada kegiatan Webinar Penyesuaian Kebijakan Pembelajaran di Masa Pandemi Covid-19, yang dilaksanakan secara virtual melalui Zoom dan disiarkan langsung dari kanal YouTube Kemendikbud RI menyatakan terdapat beberpa kendala yang dihadapi guru, orangtua, dan peserta didik selama PJJ setidaknya meliputi: 1) Guru mengalami hambatan dalam PJJ dan cenderung fokus kepada penuntasan kurikulum, 2) Waktu pembelajaran menjadi berkurang, sehingga guru tidak dapat memenuhi beban jam mengajarnya, 3) Guru mengalami kesulitan komunikasi dengan orangtua sebagai pembimbing peserta didik di rumah, 4) Belum semua orangtua bersedia dan mampu mendampingi anak belajar di rumah karena ada tanggung jawab yang lain seperti urusan kerja, urusan rumah, dan sebagainya, 5) Orangtua mengalami kesulitan dalam memahami pelajaran dan memotivasi anak saat mendampingi belajar di rumah, 6) Peserta didik 
mengalami kesulitan untuk konsentrasi dalam belajar dari rumah dan mengeluhkan banyaknya penugasan soal dari guru, 7) Meningkatnya rasa stress dan jenuh akibat isolasi di rumah secara berkelanjutan berpotensi menimbulkan rasa cemas dan depresi bagi anak, akses ke sumber belajar, baik karena masalah jangkauan listrik atau internet, maupun dana untuk aksesnya.

Selanjutnya dilansir dari kabar24.bisnis.com Menteri Pendidikan dan Kebudayaan (Mendikbud) mengungkapkan bahwa untuk mengatasi berbagai kendala tersebut, Kemendikbud telah melakukan sejumlah langkah inisiatif seperti program guru berbagi, seri Bimtek daring, seri webinar, penyediaan kuota gratis, relaksasi BOS dan BOP, Ruang Guru Paud dan Sahabat Keluarga. Akan tetapi upaya tersebut belum mampu mencapai PJJ efektif dan efisien. Kendala yang paling umum dirasakan terutama sekolah yang ada di pelosok adalah infra struktur yang kurang memadai serta guru belum terbiasa dengan pembelajaran berbasis digital (Listyarti, 2020).

Dibutuhkan sebuah strategi atau solusi guna menghilangkan ketimpangan antara pembelajaran jarak jauh yang diharapkan dengan kondisi sebenrnya yang terjadi, sehingga tidak berdampak pada kualitas pendidikan diberbagai jenjang (Heni, 2021). Salah satu upaya yang bisa dilakukan adalah memberikan pelatihan dan pendampingan kepada guru tentang pembelajaran bebrbasis digital. Tujuan dari pelatihan dan pendampingan tersebut adalah untuk membiasakan guru dengan pembelajaran berbasis digital. Sehingga harapan pembelajaran online yang efektif dan efisien dapat tercapai.

Upaya menurut Kamus Besar Bahasa Indonesia (KBBI) Kamus versi online/daring (dalam jaringan) usaha; ikhtiar (untuk mencapai suatu maksud, memecahkan persoalan, mencari jalan keluar, dan sebagainya). Sehingga program pengabdian ini merupakan usaha memiliki pengetahuan atau kemampuan untuk menggunakan teknologi informasi dan komunikasi (TIK) dalam proses belajar mengajar.

Kompetensi adalah kemampuan individu untuk melaksanakan suatu pekerjaan denagn benar dan memiliki keunggulan yang didasarkan pada halhal yang menyangkut pengetahuan, keahlian dan sikap (Emron, Yohni, Imas, 2016). 
Informasi dan komunikasi sebagian dari teknologi yang sedang berkembang pesat mempengaruhi kehidupan dan perubahan cara hidup dan aktivitas manusia sehari-hari termasuk dalam bidang pendidikan, pendidikan sedang mengalami perkembangan sangat pesat diantaranya dengan adanya pembelajaran digital (digital learning) dengan memanfaatkan perkembangan teknologi informasi dan komunikasi pendidikan dapat menjangkau ke seluruh lapisan masyarakat (Munir, 2017). Pembelajaran berbasis digital adalah proses belajar mengajar yang memanfaatkan teknologi informasi dan komunikasi sebagai medianya.

\section{Metode}

Sasaran dari program pengabdian kepada masyarakat ini adalah semua guru mata pelajaran yang ada di Madrasah Ibtidaiiyah Azzainiyah 2 yang berlokasi di dusun Grinting desa Karanganyar kecamatan Paiton Kabupaten Probolinggo Jawa Timur. Program pengabdian kepada masyarakat ini dilaksanakan pada tahun 2021 yaitu pada masa pemerintah mewajibkan pelaksanaan pembelajaran pada setiap satuan pendidikan diseluruh tanah air agar dilaksanakan secara daring atau pembelajaran jarak jauh (PJJ) akibat adanya wabah Covid-19 yang menyerang seluruh dunia. Penyelenggaraan pembelajaran jarak jauh atau pembelajaran online memerlukan beberapa aspek, yaitu: interaksi yang cukup antara siswa dan guru; pembelajaran dirancang dengan baik; guru yang memiliki dedikasi, motivasi,serta memiliki kompetensi (Ali \& Ahmad, 2011). Hakikat dari pembelajaran online bukanlah meniadakan interaksi antar guru dan siswa, tetapi memanfaatkan fungsi teknologi dalam pembelajaran (Heni, 2021). Salah satu kompetensi guru yang dibutuhkan dalam proses pembelajaran jarak jauh adalah mampu menggunakan perangkat teknologi informasi dan komunikasi (TIK) secara trampil.

Metode yang digunakan dalam program pengabdian kepada masyarakat ini adalah pelatihan dan pendampingan, yang bertujuan untuk meningkatkan pemahaman serta ketrampilan dalam penggunaan perangkat teknologi informasi dan komunikasi dalam menunjang proses pembelajaran berbasis digital khususnya dimasa pandemi Covid-19..

Tahapan - tahapan kegiatan yang dilakukan pada pengabdian kepada masyarakat disajikan pada diagram berikut ini: 


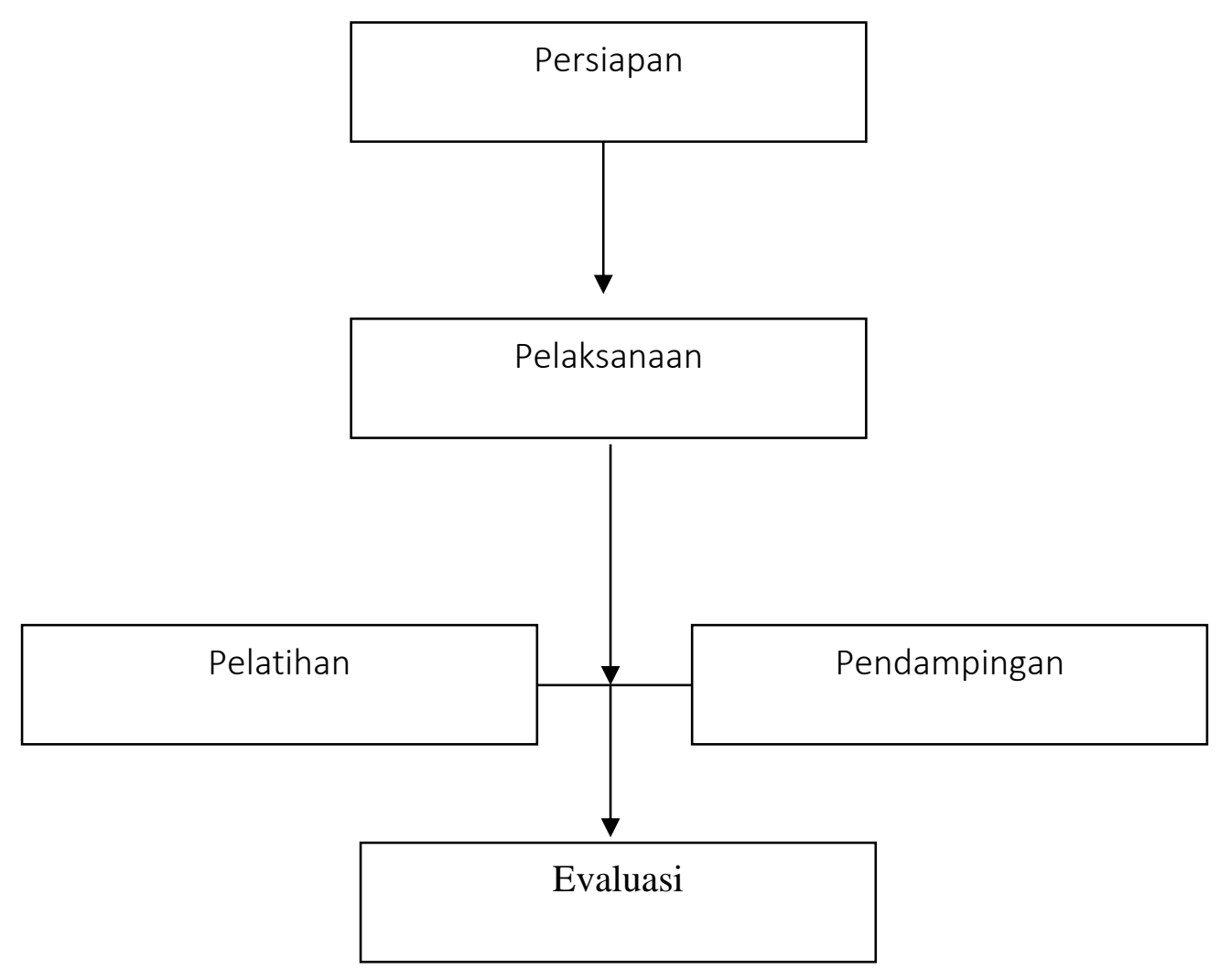

Diagram tahapan kegiatan PkM (sumber perancangan)

\section{Tahap Persiapan}

Agar pelaksanaan kegiatan berjalan seperti yang diarapkan maka perlu adanya persiapan yang meliputi: pembuatan surat permohonan, penentuan tanggal kegiatan, pembagian tugas dengan tim dan persiapan materi serta penyusunan acara pelatihan dan pendampingan.

\section{Tahap Pelaksanaan}

\section{Pelaksanaan Pelatihan}

Pada tahap pelaksaan pelatihan penyaji memaparkan materi yang terkait dengan pembelajaran berbasis online, mulai dari pemaparan tentang kebijakan pembelajaran onlie, pentingnya pembelajaran online dimasa pandemi, media yang digunakan, infrastruktur yang mendukung, materi pembelajaran, sumber ajar serta aplikasi pembelajaran yang direkomendasikan. 
Pelaksaan pelatihan mengambil objek Madrasah Ibtidaiyah Azzainiyah ॥ yang berlokasi di desa Karanganyar dusun Grinting Paiton Probolinggo. Pelatihan dilakukan secara tatap muka namun tetap menjalankan protokol kesehatan. Setelah selesai memberikan materi secara ceramah selanjutnya peserta dipersilahkan untuk mempraktekkan hasil dari pelatihan yaitu bagaimana menggunakan Teknologi Informasi dan Komunikasi sebagai alat pendukung pembelajaran berbasis online.

\section{Pelaksanaan Pendampingan}

Metode pendampingan yang digunakan adalah satu peserta diampingi oleh satu rang dari tim. Pada saat peserta mempraktekkan pembelajaran berbasis online tiap peserta didampingi oleh satu orang ari tim pengabdian. Maksud dari metode ini adalah agar waktu dapat digunakan secara efisien serta hasil yang memuaskan. Karena ketika peserta mengalami kesulitan bisa langsung bertanya kepada pendamping, sehingga kesulitan yang dihadapi peserta langsung teratasi.

\section{Tahap Evaluasi}

Tahapan ini adalah tahapan terakhir dalam pelatihan dimana untuk mengetahui hasil dari pelatihan, peserta dipersilahkan untuk mempresentasikan hasil dari apa yang telah dilakukan / dipraktekkan selama pelatihan dan pendampingan.

\section{Hasil}

Hampir seluruh peserta yakni 20 orang guru dalam pelatihan ini dapat mengikuti meteri pembelajaran berbasis digital, hasil dapat dilihat pada tabel 1: 
Tabel 1: Hasil telaah penyusunan materi berbasis digital oleh peserta

\begin{tabular}{|c|l|c|c|}
\hline \multirow{2}{*}{ No. } & \multicolumn{1}{|c|}{ Indikator } & \multicolumn{2}{|c|}{ Kategori } \\
\cline { 3 - 4 } & & \multicolumn{1}{|c|}{ Ya } & Tidak \\
\hline 1 & $\begin{array}{l}\text { Pelatihan mencakup pembukaan, inti dan } \\
\text { penutup }\end{array}$ & 18 & 2 \\
\hline 2 & Bahasa yang digunakan komunikatif & 19 & 1 \\
\hline 3 & Ada tugas dan evaluasi & 20 & 0 \\
\hline 4 & Materi sesuai dengan kebutuhan & 18 & 2 \\
\hline 5 & Penugasan dan pendampingan & 17 & 3 \\
\hline 6 & $\begin{array}{l}\text { Media yang digunakan sesuai dengan } \\
\text { kemampuan peserta }\end{array}$ & 20 & 0 \\
\hline
\end{tabular}

Berdasarkan hasil koreksi yang dilakukan oleh tim pengabdian terhadap model pembelajaran berbasis online yang dilakukan oleh peserta pelatihan $95 \%$ hasilnya baik materi yang disususn sudah sesuai dengan harapan. Hanya sekitar $5 \%$ dari total peserta yang masih kaku dalam membuat pembelajaran bebasis online, hal ini disebabkan karena peserta tersebut belum terampil dalam penggunaan media berbasis digital.

\section{Tanggapan Peserta Pelatihan}

Agar hasil pelatihan dapat diketahui bersama maka pada akhir pelatihan peserta diberikan angket agar dapat menilai terhadap adanya pelatihan. Angket dibagi dalam 3 aspek utama yaitu aspek alokasi waktu, kegunaan serta aspek penyajian. Kemudian masing-masing aspek diberikan indikator seperti ditunjukkan pada tabel berikut: 
Tabel 2: Angket tanggapan peserta pelatihan

\begin{tabular}{|l|l|l|l|l|l|l|l|}
\hline \multirow{2}{*}{ No. } & \multicolumn{5}{|c|}{ Kategori } & \multirow{2}{*}{ Jumlah } \\
\cline { 3 - 7 } & $\begin{array}{l}\text { Aspek } \\
\text { Sangat } \\
\text { tidak baik }\end{array}$ & $\begin{array}{l}\text { Tidak } \\
\text { baik }\end{array}$ & Baik & $\begin{array}{l}\text { Cukup } \\
\text { baik }\end{array}$ & $\begin{array}{l}\text { Sangat } \\
\text { baik }\end{array}$ & Ketersediaan waktu \\
\hline 1. & $\begin{array}{l}\text { Durasi } \\
\text { pelatihan } \\
\text { memadai }\end{array}$ & 0 & 1 & 1 & 2 & 16 & 20 \\
\hline 2. & $\begin{array}{l}\text { Pelaksanaan } \\
\text { pelatihan } \\
\text { tepat waktu }\end{array}$ & 0 & 0 & 2 & 2 & 16 & 20 \\
\hline
\end{tabular}

Tabel 3: Angket tanggapan peserta pelatihan

\begin{tabular}{|c|c|c|c|c|c|c|c|}
\hline \multirow{2}{*}{ No. } & \multirow{2}{*}{ Aspek } & \multicolumn{5}{|c|}{ Kategori } & \multirow[b]{2}{*}{ Jumlah } \\
\hline & & $\begin{array}{l}\text { Sangat } \\
\text { tidak } \\
\text { baik }\end{array}$ & $\begin{array}{l}\text { Tidak } \\
\text { baik }\end{array}$ & Baik & $\begin{array}{l}\text { Cukup } \\
\text { baik }\end{array}$ & $\begin{array}{l}\text { Sangat } \\
\text { baik }\end{array}$ & \\
\hline \multicolumn{8}{|c|}{ Kegunaan materi } \\
\hline 1. & $\begin{array}{l}\text { Materi } \\
\text { pelatihan } \\
\text { membantu } \\
\text { para guru }\end{array}$ & 0 & 1 & 2 & 2 & 15 & 20 \\
\hline 2. & $\begin{array}{l}\text { Materi } \\
\text { pembelajar } \\
\text { an berbasis } \\
\text { online } \\
\text { dibutuhkan } \\
\text { saat ini }\end{array}$ & 0 & 0 & 3 & 3 & 14 & 20 \\
\hline
\end{tabular}


Tabel 4: Angket tanggapan peserta pelatihan

\begin{tabular}{|c|c|c|c|c|c|c|c|}
\hline \multirow[b]{2}{*}{ No. } & \multirow{2}{*}{ Aspek } & \multicolumn{5}{|c|}{ Kategori } & \multirow[b]{2}{*}{ Jumlah } \\
\hline & & $\begin{array}{l}\text { Sangat } \\
\text { tidak baik }\end{array}$ & $\begin{array}{l}\text { Tidak } \\
\text { baik }\end{array}$ & Baik & $\begin{array}{l}\text { Cukup } \\
\text { baik }\end{array}$ & $\begin{array}{l}\text { Sangat } \\
\text { baik }\end{array}$ & \\
\hline \multicolumn{8}{|c|}{ Narasumber } \\
\hline 1. & $\begin{array}{l}\text { Bahasa yang } \\
\text { digunakan } \\
\text { mudah } \\
\text { dimengerti }\end{array}$ & 0 & 0 & 3 & 2 & 15 & 20 \\
\hline 2. & $\begin{array}{l}\text { Materi } \\
\text { sesuai } \\
\text { dengan } \\
\text { yang } \\
\text { direncanaka } \\
\mathrm{n}\end{array}$ & 0 & 0 & 2 & 4 & 14 & 20 \\
\hline
\end{tabular}

Berdasarkan hasil dari angket yang diisi oleh peserta menunjukkan bahwa dari ketiga aspek tanggapan peserta sangat baik. Dari aspek ketersediaan waktu lebih dari 70\% tanggapan peserta kategori sangat baik, pernyataan peserta adalah waktu yang disediakan sudah sesuai dengan jadwal yang telah disepakati. Kemudian dari aspek kegunaan materi lebih dari $70 \%$ tanggapan peserta kategori sangat baik, pernyataan peserta adalah bahwa materi yang seperti ini sangat dibutuhkan saat ini dan yang akan datang, dan dari aspek narasumberu lebih dari 70\% tanggapan peserta kategori sangat baik, pernyataan peserta adalah bahwa narasumber menggunakan bahasa yang mudah dipahami serta ketika pendampingan pera anggota tim sabar dalam memberikan pendampingan.

\section{Pembahasan}

Kegiatan Pengabdian Kepada Masyarakat ini dilakukan di Madrasah Tsanawiyah Azzainiyah 2 sebagai sasaran kigiatan lokasinya di desa 
Karanganyar kecamatan Paiton Kabupaten Probolinggo. Peserta dari kegiatan ini adalah semua guru mata pelajaran di Madrasah Tsanawiyah Azzainiyah 2.

\section{Persiapan Pelatihan}

Sebelum kegiatan pelatihan dilaksanakan maka tim pengabdian perlu melakukan kegiatan persiapan terlebih dahulu dimana pada kegiatan ini pihak tim melakukan koordinasi dengan pihak Madrasah Tsanawiyah Azzainiyah 2 melalui surat permohonan untuk melakukan kegiatan pelatihan tentang pembelajaran berbasis online. Setelah dihasilkan kesepakatan antara tim pengabdian dan pihak Madrasah Tsanawiyah Azzainiyah 2, maka tim mempersiapkan materi apa saja yang telah disepakati bersama, penentuan waktu, jumlah peserta yang akan mengikuti kegiatan serta susunan acara kegiatan.

\section{Pelaksanaan Pelatihan}

Pelatihan dilakukan di Madrasah Tsanawiyah Azzainiyah 2 yang berlokasi di dusun Grinting desa Karanganyar Paiton Probolinggo. Peserta pelatihan adalah semua guru mata pelajaran. Lama kegiatan ini kurang lebih 2 jam yang meliputi pembukaan yang di sampaikan oleh perwakilan dari Madrasah Tsanawiyah Azzainiyah 2, kemudian dilanjutkan pemaparan materi oleh perwakilan dari tim pengabdian. Setelah dua sesi acara selesai kemudian dilanjutkan sesi ketiga yaitu pemberian tugas mandiri ke masing-masing peserta. Pada tugas mandiri ini tiap - tiap peserta didampingi oleh satu orang nggota tim pengabdian. Diantara tugas yang diberikan dalam tugas mandiri adalah pertama pembuatan grup di WhatsApp, WhatsApp dipilih sebagai bahan pelatihan karena WhatsApp lebih faniliar dan umum digunakan dikalangan guru-guru madrasah. Setelah selesai pembuatan grup kemuadian dilanjutkan persiapan materi, pada tahap ini peserta harus mempersiapkan materi yang akan diberikan kepada siswa melalui pesan WhatsApp, langkah selanjutnya mengirim materi ke grup masing-masing pata pelajaran.

Sesi akhir dari pelatihan ini adalah koreksi hasil penugasan, pada bagian ini tim menelaah hasil dari penugasan yang diberikan dalam pelatihan, dan untuk mengetahui respon dan hasil pelatihan peserta tim juga menyebarkan 
angket kepada peserta pelatihan. Diantara hasil koreksi dari tim maka hasil dan respon peserta pelatihan adalah sebagai berikut:

\section{Kesimpulan}

Berdasarkan hasil analisis tanggapan peserta dapat disimpulkan bahwa pelaksanaan pengabdian kepada masyarakat telah berjalan sesuai dengan yang diharapkan. Terukti dengan tanggapan peserta bahwa pelatihan ini dapat meningkatkan pengetahuan dan kemampuan guru dalam penggunaan teknologi informasi dan komunikasi (TIK) dalam rangka memenuhi tuntutan jaman yaitu pembelajaran berbasis digital. Kedepannya pelatihan yang semacam ini perlu tingkatkan terutama alokasi waktunya agar ditambah, sehingga peserta pelatihan dapat lebih banyak belajar tentang pembelajaran berbasis online khususnya dimasa pandemi Covid-19 ini.

\section{Pengakuan}

Program pengabdian kepada masyarakat ini merupakan hasil kolaborasi dosen dan mahasiswa yang dikemas dalam program Kuliah Kerja Nyata mahasiswa Unuversitas Nurul Jadid Paiton Probobolinggo Dalam program Kuliah Kerja Nyata ini ada banyak manfaat yang dapat diambil baik oleh pihak Unuja, pihak dosen maupun pihak mahasiswa. Luaran dari program ini adalah sebagai bukti bahwa seluruh dosen Unuja aktif dalam melakukan tri dharma perguruan tinggi. Dalam melakukan penelitian dan pengabdian dosen telah banyak dibantu oleh masiswa sedangkan mahasiswa sejak dini telah dibimbing untuk melakukan penelitian serta bagaimana berinteraksi langsung dengan masyarakan dalam bentuk pengabdian. Syukur Alhamdulillah kami ucapkan atas kemudahan dan dukungan yang telah diberikan oleh pihak Unuja, mahasiswa, rekan-rekan dosen serta pihak LP3M yang telah banyak membantu atas suksesnya program ini.

\section{Referensi}

Abdul Rozak Fahrudin, (2020), permasalahan-dan-solusi-pembelajaran-jarakjauh-di-masa-pandemi-Covid-19/ https://sapos.co.id/2020/11/29/

Fitri Sartina Dewi (2020), Nadiem akui pelaksanaan pjj tak mudah ini kendalanya https://kabar24.bisnis.com/read/20200807/79/1276512/ 
Edison, Emron, Yohni anwar, Imas komariyah (2016) Manajemen Sumber Daya Manusia. Bandung: Alfabeta.

Hendri Dony Hahury, Fransisca Soselisa (2020), Strategi penghidupan rumah tangga pedesaan dalam menghadapi dampak pandemi Covid-19, Universitas Negeri Surabaya.

Heni Purwa Pamungkas, Ni'matushSholikhah, Jun Surjanti, Norida Canda Sakti (2021), Workshop model pembelajaran berbasis online sebagai alternatif pembelajaran ekonomi di era Covid-19, Universitas Negeri Surabaya.

Kamus Besar Bahasa Indonesia (KBBI) Kamus versi online/daring (dalam jaringan) diakses Agustus 2021

Listyarti, R. (2020). Catatan Hardiknas 2020, KPAl: Praktik merdeka belajar danpembelajaranmenyenangkan masih jauh dari harapan. Diakses Mei 2021 dari https://www.fokuspantura.com

Muhklison (2020), kendala-pembelajaran-jarak-jauh-dan-solusinya/ https://www.stit-alkifayahriau.ac.id/

Munir, (2017), Pembelajaran Digital, Jakarta: Rineka Cipta.

Santi Susanti, (2021), Peluang dan tantangan bisnis kriya saat pandemi Covid19, Universitas Negeri Surabaya.

Saubani, A.(2020) gagap pembelajaran daring ditengah wabah corona, diakses Mei 2021 dari https://republika.co.id

UNICEF, IRC, \& WHO. (2020). Key messages and actions for COVID-19 prevention and control in school. diakses Mei, 2021 https://www.who.int 